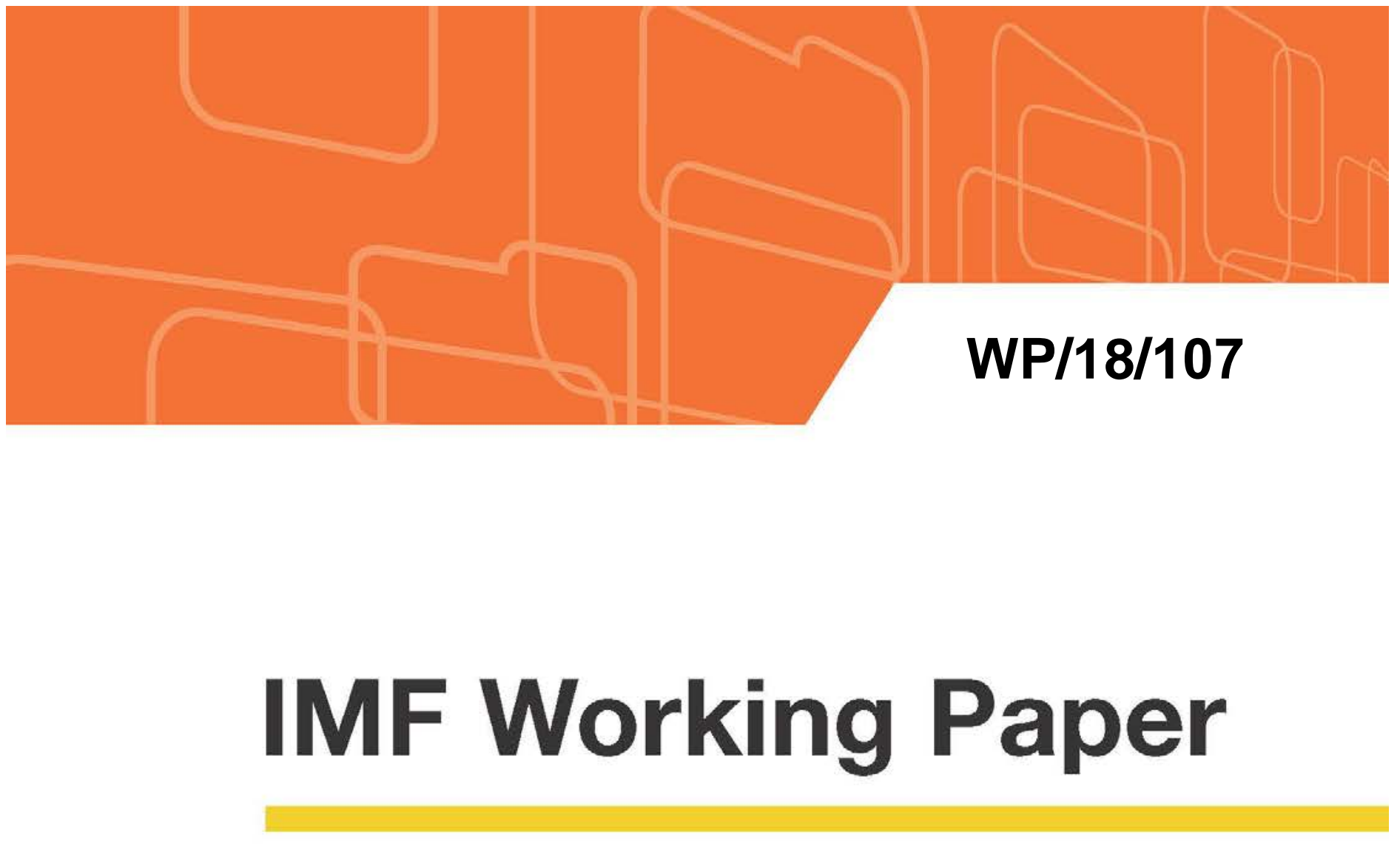

\title{
Real Exchange Rates, Economic Complexity, and Investment
}

Steve Brito, Nicolas E. Magud, and Sebastian Sosa

IMF Working Papers describe research in progress by the author(s) and are published to elicit comments and to encourage debate. The views expressed in IMF Working Papers are those of the author(s) and do not necessarily represent the views of the IMF, its Executive Board, or IMF management.

$$
\text { I N T E R N A T I O N A L M O N E T A R Y F U N D }
$$




\title{
IMF Working Paper
}

Institute for Capacity Development

\section{Real Exchange Rates, Economic Complexity, and Investment \\ Prepared by Steve Brito, Nicolás E. Magud, and Sebastián Sosa}

Authorized for distribution by Charles Kramer

May 2018

\section{IMF Working Papers describe research in progress by the author(s) and are published to elicit comments and to encourage debate. The views expressed in IMF Working Papers are those of the author(s) and do not necessarily represent the views of the IMF, its Executive Board, or IMF management.}

\begin{abstract}
We show that the response of firm-level investment to real exchange rate movements varies depending on the production structure of the economy. Firms in advanced economies and in emerging Asia increase investment when the domestic currency weakens, in line with the traditional Mundell-Fleming model. However, in other emerging market and developing economies, as well as some advanced economies with a low degree of structural economic complexity, corporate investment increases when the domestic currency strengthens. This result is consistent with Diaz Alejandro (1963) — in economies where capital goods are mostly imported, a stronger real exchange rate reduces investment costs for domestic firms.
\end{abstract}

JEL Classification Numbers: E22, F31, F41.

Keywords: Firm-level investment, real exchange rate, misalignment

Author’s E-Mail Address: sbrito@imf.org; nmagud@imf.org; ssosa@imf.org 


\section{INTRODUCTION}

The classical Mundell-Fleming model for open economies (Mundell, 1963, Fleming, 1962) suggest that a weaker domestic currency should stimulate investment, as it makes domestic goods cheaper and thus more competitive in foreign markets. This will entice an increase in production and exports, while domestic demand tilts to non-tradable goods. Diaz Alejandro (1963), however, argues that for economies that depend on imported capital goods, investment increases when the domestic currency strengthens - to the extent that purchasing foreign capital goods becomes cheaper. These opposing effects could ultimately reflect different degrees of economic complexity (Hausmann and Hidalgo, 2011).

To bridge these two apparently opposing views, we propose a simple theoretical framework that motivates our empirical analysis. We find that the relationship between real exchange rate movements and investment varies across regions and structural economic characteristics. In advanced economies, firms' investment is positively associated with a real exchange rate depreciation. Similar results are found for emerging economies in Asia. By contrast, in other emerging market and developing regions corporate investment is higher when the local currency strengthens in real terms. In short, for corporate investment, the Mundell—Fleming story holds for advanced economies and for emerging Asia. Price competitiveness appears to be a key determinant of firms’ investment decisions. By contrast, Diaz Alejandro's argument seems to dominate in all other cases, as the cost of importing capital goods outweighs the positive effects of higher competitiveness. We also show that underlying these findings is the degree of economic complexity. For firms in more complex economies (which generally include most advanced economies as well as emerging Asia), the positive impact of a real exchange rate depreciation on price competitiveness tends to outweigh the negative impact associated with increased cost of imported capital goods. But it is the opposite in firms in economies with a lower degree of complexity, which basically include all other emerging market regions. We also analyze the above exercise for a simple measure of real exchange rate misalignment. Most of the above results carry through, except that advanced economies that are less complex behave as emerging markets other than Asian, in that corporate investment increases when their currencies are overvalued.

We focus on investment at the firm level rather than aggregate investment levels. This has important advantages. The degree of real exchange rate misalignment is totally exogenous to individual firms, regardless of their size. By contrast, using aggregate investment instead of firm-level data could introduce endogeneity issues. Adjustments in the external current account-simply aggregate saving (a typically very slow-moving variable) net of aggregate investment-are tightly associated with movements and misalignments of the real exchange rate. By counting on firm-level data, we mitigate substantially these potential endogeneity issues-as reverse causality is not possible. This approach also prevents potential problems related to investment deflators, as these could be affected by movements in the real exchange 
rate. ${ }^{1}$ Yet, as Figure 1 shows and Magud and Sosa (2017) document, firm-level investment is highly correlated with aggregate investment.

Figure 1: Corporate Investment and Total Private Investment

(Year-over-year percent change)

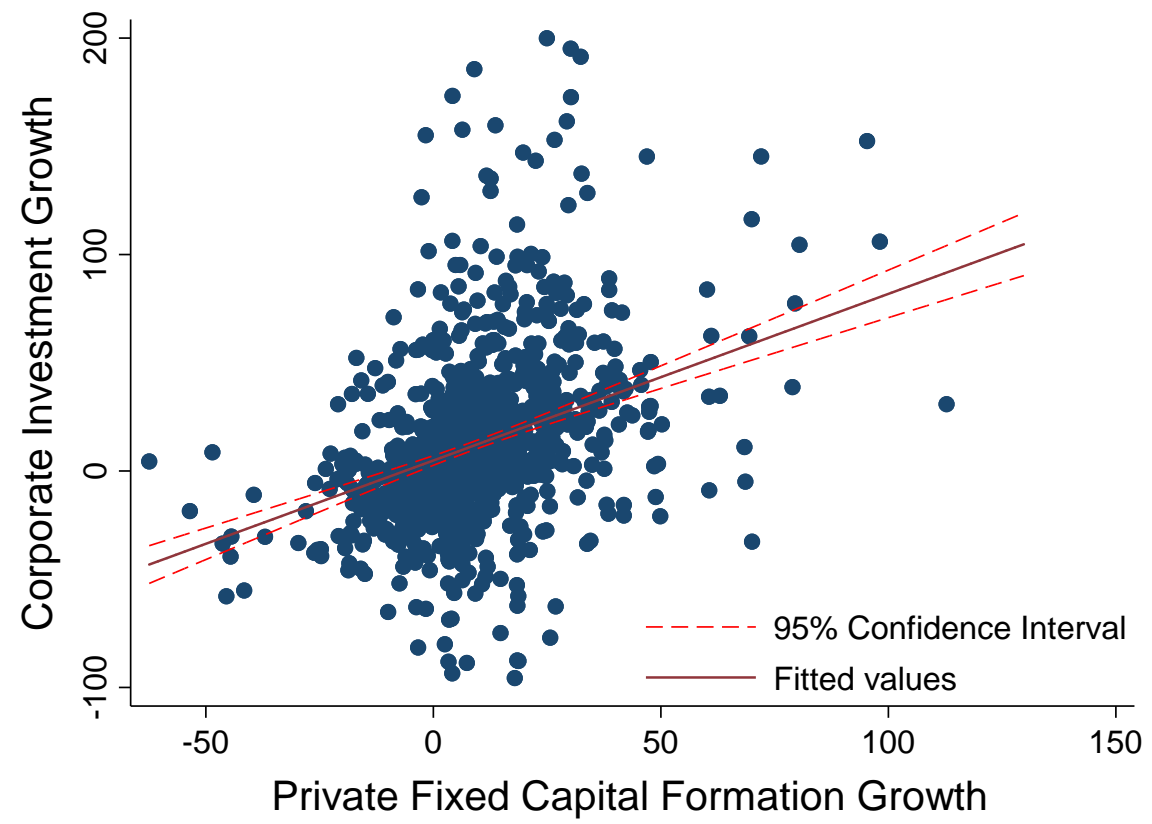

Source: authors' calculations based on IMF's International Financial Statistics and Thompson Reuters’ Worldscope.

Our paper contributes to a strand of the literature looking at the relationship between the real exchange rate and investment and growth. The closest paper to ours is Alfaro and others (2017). They focus on the impact of real exchange rate movements on firm-level TFP growth and $R \& D$ investment. They find that these variables are positively associated with real depreciations in emerging Asia but with real appreciations in other emerging market regionswith no clear relationship in advanced economies. The key transmission channel is given by the relative response of exports and imports. Economies that are more export-intensive (implying a lower dependence on importing capital) increase corporate R\&D and TFP growth when the real exchange rate depreciates. Less export-intensive countries do it when the domestic currency appreciates. ${ }^{2}$ Dao and others (2017) also study the relationship between the real exchange rate and corporate investment using firm-level data. However, they use a different measure of the real exchange rate, which is not weighted by trade partners - and therefore is more weakly associated with competitiveness ${ }^{3}$ - and focus on the labor cost reduction associated with real depreciations. Another key difference is that we split the sample

\footnotetext{
${ }^{1}$ For a recent study on exchange rate pass-through see Carriere-Swallow and others (2016).

${ }^{2}$ Avellan and Ferro (2018) document similar findings for Ecuador/

${ }^{3}$ Moreover, such a measure is neither a correct measure of competitiveness, nor a measure of real income.
} 
by region or economic structure, allowing us to uncover important differences masked in the aggregate results. Also related to our work is Lanau (2017), who also examines regional differences, but his focus is on the impact of real exchange depreciations on firm-level growth, without analyzing firms' investment.

Avdjiev and others (2017) document how firm-level investment in emerging markets and the U.S. dollar cycle are related, and find that a stronger U.S. dollar is associated with lower firmlevel investment in emerging economies, owing to balance sheets' currency mismatches affecting firms' decisions through the financial channel. ${ }^{4}$ Similarly, Druck and others (2018), examine the impact of the U.S. dollar cycle on emerging market and developing countries' growth. They show that these effects are more prominently associated to income effects, especially when controlling for financial/currency mismatches effects.

We build on this literature and contribute to it by exploring the relationship between real exchange rate movements and firm-level investment. Our main contribution is to document how this relationship varies across regions, and particularly across economies with different production structures, which to best of our knowledge has not been explored before. ${ }^{5}$

The rest of the paper is structured as follows. Section II sketches the theoretical model, showing that corporate investment can either increase or decrease when the currency strengthens (or weakens) -implying that in the end, it is an empirical issue. Section III describes the data, while Section IV presents the econometric model. Results are shown in Section V, with some robustness checks included in Section VI. Section VII concludes.

\section{A THEORETICAL MODEL}

We use an augmented Q-model of investment for a price-taking open economy to motivate the empirical analysis below. The problem of a firm $i$ in period $t$ that produces tradable goods and purchases tradable investment goods over an infinite horizon is to maximize the present discounted value of the flow of dividends, $D_{t}$, given by

$$
E_{t}\left\{\sum_{i=1}^{\infty} \frac{D_{t+i}}{R^{i}}\right\}
$$

where $R$ stands for the exogenous gross interest rate. In turn, the firms' dividend flows are given by

$$
D_{t}=\pi\left(K_{t}, \theta_{t}, e_{t}\right)-e_{t} I_{t}-c\left(I_{t}, K_{t}\right)
$$

\footnotetext{
${ }^{4}$ See also Caballero (2018)

${ }^{5}$ An older literature focused on the contractionary effects of devaluations (e.g., Krugman and Taylor, 1978) and on the contractionary effects of currency mismatches (Krugman 1999, Cespedes and others, 2004).
} 
where $\pi$ is the firm's profit function, $K$ the stock of capital, $\theta$ the level of technology, and $e$ is the real exchange rate. $I$ denotes investment and $c\left(I_{t}, K_{t}\right)$ represents a function to capture the adjustment cost of investment. The profit function is assumed to be increasing in capital, the level of technology, and the real exchange rate, and it is a concave function. Adjustment costs of installing new capital are an increasing and convex function in the investment-capital ratio, $\frac{I_{t}}{K_{t}}$, defined below, and $\theta_{t}$ is a stationary first order Markov process. Given a constant rate of depreciation $\delta$, the stock of capital changes over time as given by

$$
K_{t+1}=I_{t}+(1-\delta) K_{t}
$$

Firms in this economy purchase its capital abroad. ${ }^{6}$ The real exchange rate is defined as the number of domestic currency baskets of tradable goods needed to purchase one unit of the foreign currency basket of tradable goods. Thus, an increase in the real exchange rate denotes a real depreciation. When the economy's real exchange rate strengthens, the economy is richer, and thus its purchasing power increases. Therefore, investment (i.e., purchasing capital goods), becomes relatively cheaper. At the same time, however, a weaker real exchange rate increases the country's competitiveness, as its tradable final goods become relatively cheaper for the rest of the world (though more expensive for domestic agents).

Formally, the firm's problem is to maximize (1) subject to (2) and (3). The Bellman equation for the firm's problem is given by

$$
V\left(K_{t}, \theta_{t}, e_{t}\right)=\max _{I_{t}, K_{t+1}}\left\{\pi\left(K_{t}, \theta_{t}, e_{t}\right)-e_{t} I_{t}-c\left(I_{t}, K_{t}\right)+\frac{1}{R} E_{t}\left[V\left(K_{t+1}, \theta_{t+1}, e_{t+1}\right)\right]\right\}
$$

Equivalently,

$$
V\left(K_{t}, \theta_{t}, e_{t}\right)=\max _{I_{t}}\left\{\pi\left(K_{t}, \theta_{t}, e_{t}\right)-e_{t} I_{t}-c\left(I_{t}, K_{t}\right)+\frac{1}{R} E_{t}\left[V\left(I_{t}+(1-\delta) K_{t}, \theta_{t+1}, e_{t+1}\right)\right]\right\}
$$

Optimizing over the control variable $I_{t}$, while $K_{t}$ is the state variable, implies the following first order condition:

$$
e_{t}+c_{I}\left(I_{t}, K_{t}\right)=\frac{1}{R} E_{t}\left[V\left(K_{t+1}, \theta_{t+1}, e_{t+1}\right)\right]=\frac{1}{R} E_{t} q_{t+1}
$$

On the right-hand side of equation (6), as usual in the literature, we define Tobin's q as the discounted shadow price of capital-marginal q-which equals the replacement cost of capital plus the adjustment cost of installing new capital, i.e., the effective price of new capital. Assume a constant-returns-to-scale adjustment cost of capital function given by

\footnotetext{
${ }^{6}$ Assuming that only a share of the capital stock is imported does not alter the results, this being only a simplifying assumption for ease of exposition.
} 


$$
c\left(I_{t}, K_{t}\right)=\frac{1}{2} b\left(\frac{I_{t}}{K_{t}}-\mu\right)^{2} K_{t}
$$

in which $\mu$ denotes the investment-capital ratio in steady state, which is associated with no adjustment costs. Intuitively, $\mu K$ is the level of investment necessary to maintain a constant stock of capital in the steady state. Substituting (7) into (6) we get

$$
e_{t}+b\left(\frac{I_{t}}{K_{t}}-\mu\right)=\frac{1}{R} E_{t}\left[V\left(K_{t+1}, \theta_{t+1}, e_{t+1}\right)\right]=\frac{1}{R} E_{t} q_{t+1}
$$

Re-arranging (8) we obtain

$$
\frac{I_{t}}{K_{t}}=\frac{1}{b R} E_{t} q_{t+1}-\frac{e_{t}}{b}+\mu
$$

which shows the standard positive association between Tobin's q and investment. As has been shown in the literature, an increase in marginal q (a higher shadow price of capital, implying a larger present discounted value of the flow of dividends, as shown below), makes the firm to optimally increase investment.

The envelope condition implies that

$$
V_{k}\left(K_{t}, \theta_{t}, e_{t}\right)=\pi_{K}\left(K_{t}, \theta_{t}, e_{t}\right)-c_{K}\left(I_{t}, K_{t}\right)+\frac{1-\delta}{R} E_{t}\left[V\left(K_{t+1}, \theta_{t+1}, e_{t+1}\right)\right]
$$

Thus,

$$
q_{t}=\left[\pi_{K}\left(K_{t}, \theta_{t}, e_{t}\right)-c_{K}\left(I_{t}, K_{t}\right)\right]+\frac{1}{R}(1-\delta) E_{t}\left[q_{t+1}\right]
$$

Updating (11) one period, forwarding it, taking expectations as of period $t$, applying the law of iterated expectations and substituting back in (11), and finally iterating forward and using the transversality condition, we obtain:

$$
V_{K}\left(K_{t}, \theta_{t}\right)=E_{t}\left\{\sum_{i=0}^{\infty}\left(\frac{1-\delta}{R}\right)^{i}\left[\pi_{K}\left(K_{t+i}, \theta_{t+i}\right)-c_{K}\left(I_{t+i}, K_{t+i}\right)\right]\right\}
$$

which shows that the marginal value of an additional unit of capital should equal the discounted flow of marginal profits, net of adjustment costs.

Re-arranging (8) and using the envelope condition (10) results in

$$
I_{t}=\left[\frac{V_{k}\left(K_{t}, \theta_{t}, e_{t}\right)-\pi_{K}\left(K_{t}, \theta_{t}, e_{t}\right)+c_{K}\left(I_{t}, K_{t}\right)}{b(1-\delta)}-\frac{e_{t}}{b}+\mu\right] K_{t}
$$

Taking the partial derivative of (13) with respect to the real exchange rate yields

$$
\frac{\partial I_{t}}{\partial e_{t}}=\left[\frac{V_{k e}\left(K_{t}, \theta_{t}, e_{t}\right)-\pi_{K e}\left(K_{t}, \theta_{t}, e_{t}\right)}{(1-\delta)}-1\right] \frac{K_{t}}{b}
$$


which shows two opposing forces at play. On the one hand, an increase in competitiveness, as given by a higher $e$, stimulates investment by making domestic goods cheaper for the rest of the world. In turn, this increases the continuation value of investment given that $V_{k e}\left(K_{t}, \theta_{t}, e_{t}\right)-\pi_{K e}\left(K_{t}, \theta_{t}, e_{t}\right)>0$. On the other hand, a higher $e$ increases the cost of purchasing capital goods. If the former effect dominates, corporate investment increases when the currency weakens). However, if the latter effect is larger, investment would decline when the domestic currency weakens, as given by

$$
\frac{V_{k e}\left(K_{t}, \theta_{t}, e_{t}\right)-\pi_{K e}\left(K_{t}, \theta_{t}, e_{t}\right)}{(1-\delta)}-1 \lesseqgtr 0
$$

Intuitively, in economies where the competitiveness channel is relatively stronger, the impact through this channel will outweigh the negative effect of higher costs of capital goods, implying that a weaker (real) currency should be associated with higher corporate investment. Investment will decrease if the relative strengths of these effects is flipped. Relatedly, the degree of economic complexity should be reflected in these two relative elasticities. In the end, how real exchange rate movements affect investment is an empirical question. We move to this next. ${ }^{7}$

\section{DATA AND DESCRIPTIVE STATISTICS}

The dataset comprises an unbalanced panel of 40,412 firms from 71 economies for the period 1995 - 2016, with annual frequency. The source of the firm-level data is Thomson Reuters Worldscope, while the country-specific real effective exchange rate (REER) data comes from the IMF's International Financial Statistics, and the global Cboe Volatility Index (VIX) from Bloomberg, L.P. We drop observations with inconsistent data ${ }^{8}$ and, to avoid outliers, we truncate the firm-level observations below the $1^{\text {st }}$ percentile and above the $99^{\text {th }}$ percentile. ${ }^{9}$ To identify the industry of firms, we use the SIC 4-digit code classification. We restrict the sample to non-financial firms, excluding firms in finance, insurance, real estate, and public administration sectors. Table 1 presents the distributions of firms and observations by industry in the sample. The largest group is manufacturing with close to 52 percent of observations the total sample, followed by services with 14 percent, and transportation, communications, and utilities with almost 10 percent.

\footnotetext{
${ }^{7}$ Adding a non-tradable sector would only enhance these results as profitability of firms in this sector would not decrease when the currency is overvalued. Adding currency mismatches and the possibility of firms' balance sheet effects would also enlarge these effects—see Magud (2008).

${ }^{8}$ Negative values of total assets; capital expenditure; property, plant, and equipment; common equity; total debt; interest expenses; and depreciations.

${ }^{9}$ For the investment ratio, leverage, and interest expense ratio the data was truncated only for observation higher than the percentile $99^{\text {th }}$, because the value for the $1^{\text {st }}$ percentile was zero.
} 
Table 1: Sample composition by industry

\begin{tabular}{lccc}
\hline Industry & No. of firms & Obs. & Percent of obs. \\
\hline Agriculture, forestry, and fishing & 496 & 4,126 & 1.2 \\
Construction & 2,049 & 18,511 & 5.3 \\
Manufacturing & 19,345 & 179,906 & 51.7 \\
Mining & 2,433 & 15,844 & 4.6 \\
Nonclassifiable & 1,093 & 9,112 & 2.62 \\
Retail trade & 2,327 & 20,914 & 6.0 \\
Services & 6,979 & 48,689 & 14.0 \\
Transportation, communications, and utilities & 3,681 & 33,143 & 9.5 \\
Wholesale trade & 2,009 & 17,904 & 5.1 \\
\hline Total & 40,412 & 348,149 & 100 \\
\hline Source: Authors'
\end{tabular}

Source: Authors' calculations based on data from Thoms on Reuters Worldscope.

The countries included in the sample and the number of firms per country are listed in Table A1 in the appendix. The sample includes companies from 39 emerging market and developing economies and 32 advanced economies. ${ }^{10}$ The sample is skewed to firms from advanced economies, in a close to two-to-one ratio, with 28,199 firms (69.8 percent of the sample) from advanced economies and 12,213 firms (30.2 percent) from emerging market and developing economies. The top-five countries with the largest shares in the database are the United States (19.1 percent), Japan (10.9 percent), China (7 percent), India (5.7 percent), and the United Kingdom (5 percent). The share of companies in tradable sectors is 66.5 percent in emerging market and developing economies and 61.2 percent in advanced economies. ${ }^{11}$

Table 2 presents summary statistics of variables in the dataset, divided into three sub-samples: full sample, emerging market and developing economies, and advanced economies. The investment-capital ratio (ICR) is computed as capital expenditure (i.e., purchase of fixed assets such as property, industrial buildings, or equipment) divided by the total net value of property, plant, and equipment in the previous year. The distribution of this variable is skewed to the right, with a few companies investing more than 100 percent of their previous year's capital stock (Figure 2). For the full sample the mean of ICR is 0.27 and the median 0.15 , with broadly similar figures for both emerging and advanced economies.

As is standard in the literature, Tobin's q is computed as market capitalization plus total assets minus common equity, divided by total assets (book value). ${ }^{12}$ Cash flow is measured as net income plus depreciation and depletion, divided by the previous year's value of property, plant, and equipment. Leverage is the ratio between total debt, net of cash stock, and total common equity. Change in debt is given by the change in the stock of debt since the previous year,

\footnotetext{
${ }^{10}$ The income classification for 'emerging market and developing economies' and 'advanced economies' are as of January 2015, as defined in the IMF's World Economic Outlook.

${ }^{11}$ We define as tradable sectors agriculture, forestry and fishing, manufacturing, mining, and wholesale trade, while all the other industries are classified as non-tradable.

${ }^{12}$ As it is usual in the literature, we approximate marginal q with average q, implicitly taking Hayashi (1982) assumptions to hold.
} 
normalized by property, plant, and equipment. Interest expense is computed as the ratio of each firm's interest bill and the capital stock of the previous period (i.e., the previous year's value of property, plant, and equipment). Sales growth measures the annual growth in net sales or revenues.

Table 2. Summary Statistics (71 countries, 1995-2016)

\begin{tabular}{lcccccc}
\hline Full sample & Obs & Mean & Median & Std. Dev. & Min & Max \\
\hline Investment-capital ratio (ICR) & 348,149 & 0.27 & 0.15 & 0.43 & 0.00 & 6.41 \\
Tobin's Q & 348,149 & 1.46 & 1.13 & 1.08 & 0.29 & 12.51 \\
Cash flow & 348,149 & 0.25 & 0.22 & 2.65 & -61.60 & 20.00 \\
Leverage & 348,149 & 0.89 & 0.50 & 1.27 & 0.00 & 12.70 \\
Interest expense ratio & 348,149 & 0.09 & 0.05 & 0.17 & 0.00 & 2.61 \\
Change in debt & 348,149 & 0.25 & 0.01 & 1.53 & -6.31 & 19.95 \\
Sales growth & 348,149 & 0.14 & 0.07 & 0.46 & -0.87 & 6.17 \\
Real Effective Exchange Rate Growth & 348,140 & 0.38 & 0.43 & 6.29 & -74.07 & 135.49 \\
Real Effective Exchange Rate Misalignment & 348,149 & -0.99 & -1.04 & 12.47 & -51.50 & 371.19 \\
Cboe Volatility Index (VIX) & 348,149 & 20.69 & 22.07 & 6.07 & 12.77 & 32.55 \\
\hline Emerging and Developing Economies & & & & & & \\
\hline Investment-capital ratio (ICR) & 100,171 & 0.27 & 0.15 & 0.44 & 0.00 & 6.40 \\
Tobin's Q & 100,171 & 1.49 & 1.11 & 1.16 & 0.29 & 12.50 \\
Cash flow & 100,171 & 0.42 & 0.22 & 1.39 & -61.35 & 19.91 \\
Leverage & 100,171 & 0.91 & 0.53 & 1.25 & 0.00 & 12.69 \\
Interest expense ratio & 100,171 & 0.11 & 0.07 & 0.18 & 0.00 & 2.61 \\
Change in debt & 100,171 & 0.28 & 0.04 & 1.35 & -6.31 & 19.91 \\
Sales growth & 100,171 & 0.17 & 0.11 & 0.45 & -0.87 & 6.17 \\
Real Effective Exchange Rate Growth & 100,171 & 1.61 & 1.56 & 6.72 & -74.07 & 135.49 \\
Real Effective Exchange Rate Misalignment & 100,171 & 2.45 & 0.17 & 14.69 & -51.50 & 371.19 \\
\hline Advanced Economies & & & & & & \\
\hline Investment-capital ratio (ICR) & 247,978 & 0.27 & 0.16 & 0.43 & 0.00 & 6.41 \\
Tobin's Q & 247,978 & 1.44 & 1.14 & 1.05 & 0.29 & 12.51 \\
Cash flow & 247,978 & 0.18 & 0.22 & 3.01 & -61.60 & 20.00 \\
Leverage & 247,978 & 0.88 & 0.49 & 1.28 & 0.00 & 12.70 \\
Interest expense ratio & 247,978 & 0.08 & 0.05 & 0.16 & 0.00 & 2.61 \\
Change in debt & 247,978 & 0.24 & 0.00 & 1.59 & -6.31 & 19.95 \\
Sales growth & 247,978 & 0.13 & 0.05 & 0.46 & -0.87 & 6.17 \\
Real Effective Exchange Rate Growth & 247,978 & -0.12 & 0.06 & 6.04 & -24.00 & 16.93 \\
Real Effective Exchange Rate Misalignment & 247,978 & -2.39 & -1.30 & 11.16 & -31.07 & 54.49 \\
\hline & & & & & &
\end{tabular}

At the country level, the REER index computes the purchasing power (which is at the same time a metric of relative competitiveness) of each economy's currency by factoring in its trading partner and export competitors, weighted by the relative importance in trade. Following the IMF methodology, an increase in the REER index represent a real appreciation of the currency. We also compute a simple, back of the envelope measure of the degree of real exchange rate misalignment, REER_Mis, calculated as the difference between the index at each point in time and its country-specific historical median, as a percentage of its median, for the period 1980-2016. This metric aims at gauging the magnitude of REER overvaluation 
(positive gap) and undervaluation (negative gap). However, such a measure of misalignment is not without problems. Some countries have definitely become richer since the $1980 \mathrm{~s}$, for which this metric will likely be biased to overvaluation. Despite the simplicity and potential bias of this metric, it is strongly in line with more complex measures, such as IMF's External Balance Assessment's measures of exchange rate misalignment (Figure 3). ${ }^{13}$

Figure 2: Histogram of Investment-Capital Ratio

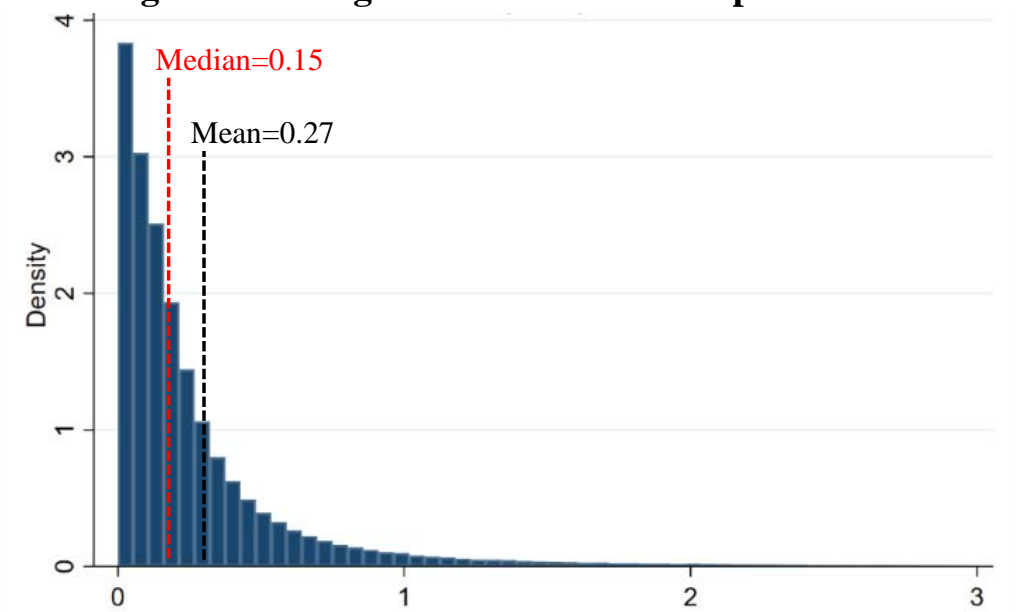

Source: Authors’ calculations based on data from Thomson Reuters Worldscope.

Figure 3: Alternative Measures of REER Misalignment, 2013-2016 (Percent)

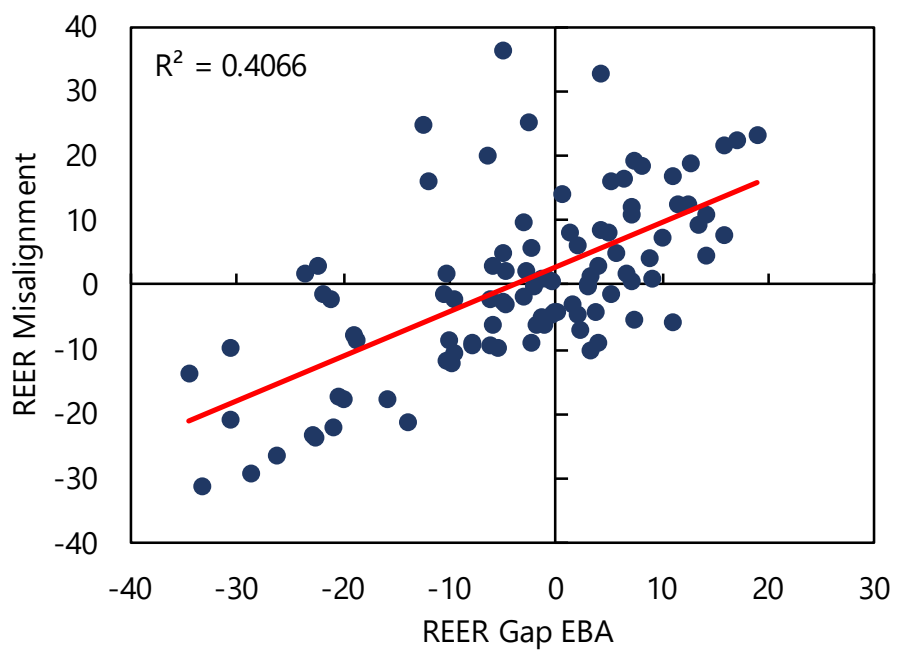

Sources: IMF, External Balance Assessment (EBA) database; IMF, Information Notice System; and IMF staff calculations.

\footnotetext{
${ }^{13}$ For details on the EBA measure see Phillips and others (2013).
} 


\section{EMPIRICAL APPROACH}

The econometric approach is a diff-in-diff firm-level panel regression. We combine firm level variables identified in the literature as determinants of investment with our measure of real exchange rate growth at the country level. The baseline specification is the following:

$$
I C R_{j, c, t}=\alpha_{j, t}+\beta * I C R_{j, c, t-1}+\gamma * R E E R_{-} g r_{c, t}+\rho * X_{j, c, t}+\sigma * V I X_{t-1}+\mu * T_{i, c, t}+\varepsilon_{j, t}
$$

The dependent variable $I C R_{j, c, t}$ denotes the investment-capital ratio for firm $j$ in country $c$ during year $t . \alpha_{j, t}$ represents a vector of firm fixed-effects. We control for the ICR of the previous year to take into account the persistence of investment. The variable $R E E R_{-} g r_{c, t}$, represents the growth rate of the REER in country $c$ during year $t$ and varies across countries and not across firms. The main focus of this study is on the effect of the REER growth on firms' investment, given by $\gamma \cdot{ }^{14} \mathrm{~A}$ negative value of $\gamma$ means firm-level investment increases when the domestic currency weakens in real terms. On the contrary, a positive coefficient implies investment at the firm level increases when the domestic currency strengthens. We explore if the effect differs across regions and/or economic productive structure. For all specifications we run standard OLS regressions with fixed effects at the firm level and robust standard errors clustered by country, to control for sample heterogeneity. In an alternative specification we replace the growth rate of the real exchange rate by the real exchange rate misalignment.

The vector of firm-level explanatory variables, $X_{j, t}$, includes the determinants of corporate investment standard in the literature (see, for example, Magud and Sosa, 2017; and Li, Magud, and Valencia, 2015). Specifically, we use Tobin's q, cash flow, leverage, change in debt, and sales growth. The VIX is also included to control for changes in global uncertainty and financial volatility. Finally, the vector $T_{i, c, t}$ is a set of year, industry-year, and country-year fixed effects dummies. Including these controls separates the effect of real exchange rate movements from that of other unobserved factors such as fiscal policy, terms of trade shocks, political shocks, etc. at the country level, as well as technological and demand changes at the industry level. To the extent possible, this set of dummy variables controls for omitted macroeconomic variables biases, acting as a control group. Lastly, $\varepsilon_{j, t}$ represents an error term.

\section{Results}

Table 3 reports the baseline results. Columns 1 and 2 show that the coefficients for the firmlevel variables exhibit the expected sign for most variables and are statistically significant for both advanced and emerging market economies. In line with the findings in previous studies,

\footnotetext{
${ }^{14}$ We follow existing literature in using the current period real exchange rate (see Alfaro and others, 2017). Presumably, the lagged ICR and the controls, in particular the set of fixed-effects, capture previous periods' real exchange rate effects.
} 
Tobin's q is positively related to firm's investment. Also consistent with previous studies, we find evidence of financial constraints, as indicated by a positive relationship between firm's cash flow and capital spending, though significant only for advanced economies. ${ }^{15}$ Moreover, all else equal, higher leverage reduces firm-level investment, while an increase in debt is associated with higher investment. Previous period sales growth also indicates a higher likelihood of profitability (also in line with accelerator models of investment), as all else equal result in higher investment.

Table 3: The dependent variable is the investment-capital ratio (ICR)

\begin{tabular}{|c|c|c|c|c|c|c|c|}
\hline VARIABLES & $\begin{array}{c}(1) \\
\text { Advanced } \\
\end{array}$ & $\begin{array}{c}(2) \\
\text { Emerging }\end{array}$ & $\begin{array}{c}\text { (3) } \\
\text { Dev. Asia }\end{array}$ & $\begin{array}{c}\text { (4) } \\
\text { Dev. Europe }\end{array}$ & $\begin{array}{l}(5) \\
\text { LAC }\end{array}$ & $\begin{array}{c}(6) \\
\text { MENA }\end{array}$ & $\begin{array}{l}(7) \\
\text { SSA } \\
\end{array}$ \\
\hline $\operatorname{ICR}(\mathrm{t}-1)$ & $\begin{array}{c}0.0645^{* * *} \\
(0.0096)\end{array}$ & $\begin{array}{c}0.0770 * * * \\
(0.0124)\end{array}$ & $\begin{array}{c}0.0744^{* * *} \\
(0.0141)\end{array}$ & $\begin{array}{c}0.0711 \\
(0.0554)\end{array}$ & $\begin{array}{c}0.1543^{* * *} \\
(0.0328)\end{array}$ & $\begin{array}{c}0.0926^{* * *} \\
(0.0196)\end{array}$ & $\begin{array}{c}0.0357 \\
(0.0129)\end{array}$ \\
\hline Tobin's Q & $\begin{array}{c}0.0495^{* * *} \\
(0.0018)\end{array}$ & $\begin{array}{c}0.0221^{* * *} \\
(0.0046)\end{array}$ & $\begin{array}{c}0.0225^{* * *} \\
(0.0054)\end{array}$ & $\begin{array}{c}0.0308 \\
(0.0246)\end{array}$ & $\begin{array}{c}0.0474 * * \\
(0.0105)\end{array}$ & $\begin{array}{c}0.0101 \\
(0.0136)\end{array}$ & $\begin{array}{c}0.0301 \\
(0.0188)\end{array}$ \\
\hline Cash flow & $\begin{array}{c}0.0013 \\
(0.0027)\end{array}$ & $\begin{array}{c}0.0402^{* * *} \\
(0.0076)\end{array}$ & $\begin{array}{c}0.0459^{* *} \\
(0.0125)\end{array}$ & $\begin{array}{c}0.0365^{* *} \\
(0.0131)\end{array}$ & $\begin{array}{c}0.0324^{* *} \\
(0.0116)\end{array}$ & $\begin{array}{c}0.0192 \\
(0.0303)\end{array}$ & $\begin{array}{c}0.0328 * * * \\
(0.0017)\end{array}$ \\
\hline Leverage (t-1) & $\begin{array}{c}-0.0190 * * * \\
(0.0018)\end{array}$ & $\begin{array}{c}-0.0244 * * * \\
(0.0031)\end{array}$ & $\begin{array}{c}-0.0251^{* * *} \\
(0.0043)\end{array}$ & $\begin{array}{l}-0.0132 \\
(0.0106)\end{array}$ & $\begin{array}{c}-0.0234^{* * *} \\
(0.0022)\end{array}$ & $\begin{array}{c}-0.0378^{* * *} \\
(0.0046)\end{array}$ & $\begin{array}{c}-0.0295 * * \\
(0.0037)\end{array}$ \\
\hline Change in debt & $\begin{array}{c}0.0397^{* * *} \\
(0.0045)\end{array}$ & $\begin{array}{c}0.0642^{* * *} \\
(0.0068)\end{array}$ & $\begin{array}{c}0.0676^{* * *} \\
(0.0103)\end{array}$ & $\begin{array}{c}0.0419 * * * \\
(0.0037)\end{array}$ & $\begin{array}{c}0.0412^{* * *} \\
(0.0040)\end{array}$ & $\begin{array}{c}0.0756^{* * *} \\
(0.0172)\end{array}$ & $\begin{array}{c}0.0572 * * * \\
(0.0023)\end{array}$ \\
\hline Sales growth (t-1) & $\begin{array}{c}0.0004^{* * *} \\
(0.0001)\end{array}$ & $\begin{array}{c}0.0002 * * \\
(0.0001)\end{array}$ & $\begin{array}{l}0.0002 * \\
(0.0001)\end{array}$ & $\begin{array}{c}-0.0001 \\
(0.0001)\end{array}$ & $\begin{array}{l}-0.0000 \\
(0.0000)\end{array}$ & $\begin{array}{c}0.0000 \\
(0.0001)\end{array}$ & $\begin{array}{c}0.0001 \\
(0.0001)\end{array}$ \\
\hline Real Effective Exchange Rate Growth & $\begin{array}{c}-0.0053^{* * *} \\
(0.0003)\end{array}$ & $\begin{array}{c}0.0010 \\
(0.0828)\end{array}$ & $\begin{array}{c}-0.0010 * * * \\
(0.0002)\end{array}$ & $\begin{array}{c}0.0049 * * * \\
(0.0013)\end{array}$ & $\begin{array}{c}0.0005^{* * *} \\
(0.0001)\end{array}$ & $\begin{array}{c}0.0274^{* * *} \\
(0.0026)\end{array}$ & $\begin{array}{c}0.0080^{* *} \\
(0.0013)\end{array}$ \\
\hline Cboe Volatility Index (VIX) (t-1) & $\begin{array}{c}-0.0019 \\
(0.0011)\end{array}$ & $\begin{array}{c}0.0021 \\
(0.2955)\end{array}$ & $\begin{array}{c}-0.0108^{* * *} \\
(0.0009)\end{array}$ & $\begin{array}{c}0.0166^{* * *} \\
(0.0041)\end{array}$ & $\begin{array}{c}0.0156 \\
(0.0091)\end{array}$ & $\begin{array}{l}0.0078^{*} \\
(0.0037)\end{array}$ & $\begin{array}{c}0.0238^{* * *} \\
(0.0013)\end{array}$ \\
\hline Constant & $\begin{array}{c}0.2995 * * * \\
(0.0277)\end{array}$ & $\begin{array}{c}0.1580 \\
(124.0342)\end{array}$ & $\begin{array}{c}0.4139 * * * \\
(0.0402)\end{array}$ & $\begin{array}{l}-0.1052 \\
(0.1463)\end{array}$ & $\begin{array}{l}-0.1102 \\
(0.1741)\end{array}$ & $\begin{array}{c}0.6270^{* * *} \\
(0.1014)\end{array}$ & $\begin{array}{c}-0.3830 * * \\
(0.0615)\end{array}$ \\
\hline Observations & 257,663 & 100,213 & 61,210 & 9,549 & 8,285 & 6,564 & 4,231 \\
\hline R-squared & 0.0789 & 0.1265 & 0.1339 & 0.1579 & 0.2074 & 0.1685 & 0.1772 \\
\hline Number of firms & 29,922 & 12,547 & 7,891 & 1,333 & 881 & 827 & 579 \\
\hline Number of countries & 32 & 39 & 7 & 8 & 6 & 11 & 4 \\
\hline
\end{tabular}

Notes: All specifications include firm, year, industry-year, and country-year fixed effects. Robust standard errors (clustered by country) are in parentheses. ${ }^{* * *} \mathrm{p}<0.01,{ }^{* *} \mathrm{p}<0.05$, ${ }^{*} \mathrm{p}<0.1$.

The relationship between real exchange rate growth and corporate investment- the focus of this study_varies across regions. Firms in advanced economies tend to invest more when their domestic currencies weaken in real terms (column 1), suggesting that price competitiveness channels play a dominant role. For emerging market and developing economies the coefficient is not statistically significant different from zero. However, this result masks differences across emerging market regions. In fact, the REER_gr coefficient is statistically different from zero for all sub-groups of countries, although the sign varies across these sub-groups. Firms in emerging Asia behave as those in advanced economies, increasing investment when their

\footnotetext{
15 See Magud and Sosa (2017), Li, Magud, and Valencia (2015), and Love (2004) for evidence on this in emerging market and developing economies, and the references therein for evidence in the U.S.
} 
countries' real exchange rate weakens, pointing to the relative importance of competitiveness as a signal for corporate investment in this region. By contrast, firms in all other emerging market and developing economies invest more when their domestic currencies strengthen in real terms. A plausible explanation for this difference is that these emerging market and developing countries tend to rely heavily on imports of foreign capital goods for domestic production, and these goods become cheaper when the local currency is overvalued. ${ }^{16}$ Related to this dependence could be the degree of economic complexity (that is, less complex economies need to import capital goods, as they typically have small and/or lowcompetitiveness industries). We elaborate on this in the next subsection.

The results are not only statistically but also economically significant. Based on the estimated coefficients, a one-standard-deviation shock to our measure of real exchange rate misalignment shifts the investment-capital ratio by about 3-4 percentage points for all regions. Given the sample ICR medians, in the neighborhood of 15 percent for both advanced economies and emerging market and developing economies (Table 2), suggest a non-trivial impact on investment resulting from real exchange rate deviations movements.

Table 4: Baseline results. The dependent variable is the investment-capital ratio (ICR)

\begin{tabular}{|c|c|c|c|c|c|c|c|}
\hline VARIABLES & $\begin{array}{c}(1) \\
\text { Advanced } \\
\end{array}$ & $\begin{array}{c}(2) \\
\text { Emerging } \\
\end{array}$ & $\begin{array}{c}\text { (3) } \\
\text { Dev. Asia } \\
\end{array}$ & $\begin{array}{c}\text { (4) } \\
\text { Dev. Europe } \\
\end{array}$ & $\begin{array}{l}(5) \\
\text { LAC } \\
\end{array}$ & $\begin{array}{c}(6) \\
\text { MENA } \\
\end{array}$ & $\begin{array}{l}(7) \\
\text { SSA } \\
\end{array}$ \\
\hline ICR (t-1) & $\begin{array}{c}0.0644^{* * *} \\
(0.0105)\end{array}$ & $\begin{array}{c}0.0779 * * * \\
(0.0124)\end{array}$ & $\begin{array}{c}0.0777 * * * \\
(0.0153)\end{array}$ & $\begin{array}{c}0.0492 \\
(0.0470)\end{array}$ & $\begin{array}{c}0.1432 * * \\
(0.0400)\end{array}$ & $\begin{array}{c}0.0964 * * * \\
(0.0288)\end{array}$ & $\begin{array}{l}0.0500 * \\
(0.0206)\end{array}$ \\
\hline Tobin's Q & $\begin{array}{c}0.0534^{* * *} \\
(0.0039)\end{array}$ & $\begin{array}{c}0.0294^{* * *} \\
(0.0055)\end{array}$ & $\begin{array}{c}0.0271 * * * \\
(0.0057)\end{array}$ & $\begin{array}{c}0.0353 \\
(0.0273)\end{array}$ & $\begin{array}{c}0.0552^{* * *} \\
(0.0097)\end{array}$ & $\begin{array}{c}0.0231 \\
(0.0179)\end{array}$ & $\begin{array}{c}0.0402 \\
(0.0289)\end{array}$ \\
\hline Cash flow & $\begin{array}{c}0.0000^{* * *} \\
(0.0000)\end{array}$ & $\begin{array}{c}0.0001 \\
(0.0001)\end{array}$ & $\begin{array}{l}0.0004 * \\
(0.0002)\end{array}$ & $\begin{array}{c}0.0001 \\
(0.0001)\end{array}$ & $\begin{array}{l}-0.0000 \\
(0.0000)\end{array}$ & $\begin{array}{c}0.0002 \\
(0.0002)\end{array}$ & $\begin{array}{c}0.0092^{* * *} \\
(0.0005)\end{array}$ \\
\hline Leverage $(t-1)$ & $\begin{array}{c}-0.0161 * * * \\
(0.0016)\end{array}$ & $\begin{array}{c}-0.0235^{* * *} \\
(0.0035)\end{array}$ & $\begin{array}{c}-0.0254^{* * *} \\
(0.0045)\end{array}$ & $\begin{array}{l}-0.0143 \\
(0.0110)\end{array}$ & $\begin{array}{c}-0.0242 * * * \\
(0.0025)\end{array}$ & $\begin{array}{c}-0.0331 * * * \\
(0.0079)\end{array}$ & $\begin{array}{c}-0.0209 * * \\
(0.0046)\end{array}$ \\
\hline Change in debt & $\begin{array}{c}0.0401^{* * *} \\
(0.0049)\end{array}$ & $\begin{array}{c}0.0662 * * * \\
(0.0080)\end{array}$ & $\begin{array}{c}0.0720 * * * \\
(0.0115)\end{array}$ & $\begin{array}{c}0.0361^{* * *} \\
(0.0047)\end{array}$ & $\begin{array}{c}0.0456 * * * \\
(0.0043)\end{array}$ & $\begin{array}{c}0.0795 * * * \\
(0.0137)\end{array}$ & $\begin{array}{c}0.0506 * * * \\
(0.0026)\end{array}$ \\
\hline Sales growth (t-1) & $\begin{array}{c}0.0364 * * * \\
(0.0067)\end{array}$ & $\begin{array}{c}0.0227^{* * *} \\
(0.0084)\end{array}$ & $\begin{array}{c}0.0278^{* *} \\
(0.0111)\end{array}$ & $\begin{array}{c}-0.0147 \\
(0.0153)\end{array}$ & $\begin{array}{c}0.0099 \\
(0.0097)\end{array}$ & $\begin{array}{c}0.0026 \\
(0.0085)\end{array}$ & $\begin{array}{l}0.0210^{*} \\
(0.0082)\end{array}$ \\
\hline REER Misalignment & $\begin{array}{c}-0.0021 * * * \\
(0.0003)\end{array}$ & $\begin{array}{c}0.0008 \\
(1.1125)\end{array}$ & $\begin{array}{c}-0.0018^{* * *} \\
(0.0001)\end{array}$ & $\begin{array}{c}-0.0052 * * * \\
(0.0007)\end{array}$ & $\begin{array}{c}0.0007^{* * *} \\
(0.0001)\end{array}$ & $\begin{array}{c}0.0134 * * * \\
(0.0013)\end{array}$ & $\begin{array}{c}0.0088^{* * *} \\
(0.0008)\end{array}$ \\
\hline Cboe Volatility Index (VIX) (t-1) & $\begin{array}{c}0.0010 \\
(0.0013)\end{array}$ & $\begin{array}{l}-0.0136 \\
(0.3616)\end{array}$ & $\begin{array}{c}0.0005 \\
(0.0031)\end{array}$ & $\begin{array}{c}0.0177 * * * \\
(0.0037)\end{array}$ & $\begin{array}{c}0.0097 \\
(0.0067)\end{array}$ & $\begin{array}{c}0.0706 * * * \\
(0.0076)\end{array}$ & $\begin{array}{c}-0.0137^{* * *} \\
(0.0012)\end{array}$ \\
\hline Constant & $\begin{array}{c}-0.0870 * * * \\
(0.0277)\end{array}$ & $\begin{array}{c}0.6120 \\
(79.5654)\end{array}$ & $\begin{array}{l}0.1910 * \\
(0.0864)\end{array}$ & $\begin{array}{c}-0.6500 * * \\
(0.1901)\end{array}$ & $\begin{array}{c}0.1715 \\
(0.1979)\end{array}$ & $\begin{array}{c}-1.8090 * * * \\
(0.1870)\end{array}$ & $\begin{array}{c}0.4387^{* * *} \\
(0.0583)\end{array}$ \\
\hline Observations & 224,592 & 91,154 & 63,092 & 8,239 & 7,522 & 5,284 & 3,852 \\
\hline R-squared & 0.0876 & 0.1180 & 0.1191 & 0.1314 & 0.1990 & 0.2147 & 0.1717 \\
\hline Number of firms & 28,226 & 12,266 & 8,052 & 1,244 & 852 & 776 & 575 \\
\hline Number of countries & 32 & 39 & 7 & 8 & 6 & 11 & 4 \\
\hline
\end{tabular}

Notes: All specifications include firm, year, industry-year, and country-year fixed effects. Robust standard errors (clustered by country) are in parentheses. ${ }^{* * *} \mathrm{p}<0.01,{ }^{* *} \mathrm{p}<0.05,{ }^{*} \mathrm{p}<0.1$.

\footnotetext{
${ }^{16}$ This has been recently documented in Alfaro and other (2017).
} 
Next, we replicate the above specification using as the main explanatory variable the real exchange rate misalignment (Table 4). Except for countries in emerging Europe, all other results remain the same.

\section{Details matter: The role of economic complexity}

Economic complexity measures the relative knowledge intensity of an economy and it can be used as a proxy for economic diversification and production capabilities to the global market (Hausmann and Hidalgo, 2011). Typically, less complex economies tend to be more commodity oriented and have less competitive manufacturing firms. Consequently, their dependence on imported capital goods is larger, especially given the value added of its exports. To explore this channel, we factor in the index of economic complexity, ECI (Hausmann, and others, 2011). Figure 4 presents the ECI by region. In panel A (left) the index is standardized from 0 to 1 - the original index is estimated from -2.6 to 2.8. The chart shows that the advanced economies and developing Europe have a higher level of economic complexity and Sub-Sahara Africa the lowest. Panel B (right) shows that developing Asia is the region with the highest increase of complexity since 1995.

Figure 4: Economic Complexity Index by Region

A. (Higher index higher complexity)

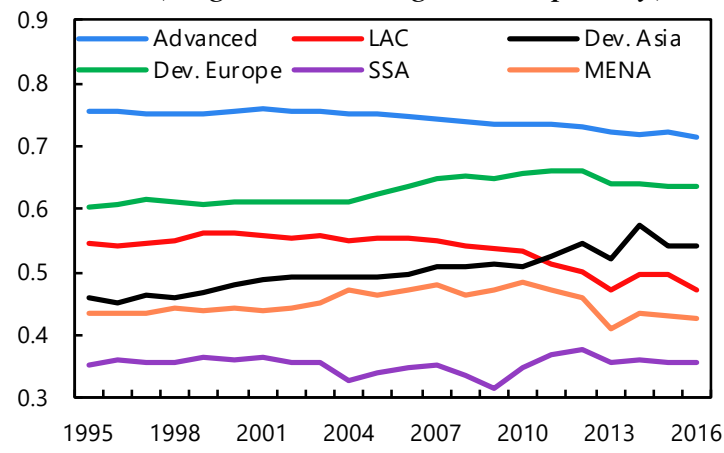

B. (Index: 1995=100)

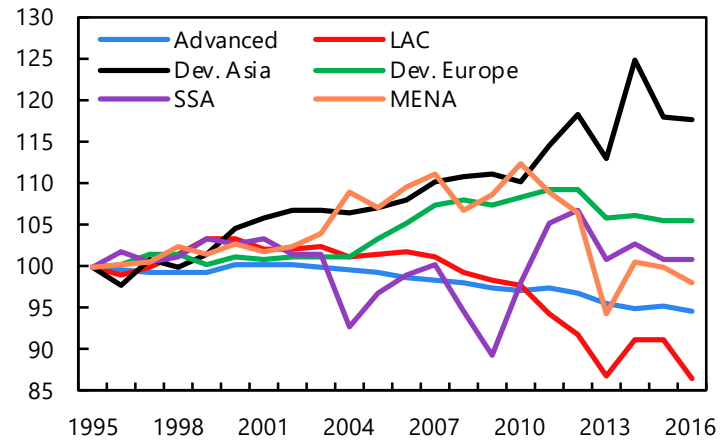

Sources: Hausmann, et al., 2011, and IMF staff calculations.

Note: the index was standardized from 0 to 1 . The original index is estimated from -2.6 to 2.8 .

We run our baseline specification separately on the set of countries that lie in the lower quartile of the ECI and on those that lie on the upper quartile. We find that for countries that are less complex, the coefficient of real exchange rate growth is positive, while for those in the upper quartile, which are the most complex and integrated, the coefficient is negative (Table 5). This suggests that for the latter group, having a lower (i.e., weaker) real exchange rate is associated with higher firm-level investment (column 2). On the contrary, for less complex economies (column 1), typically associated to those more dependent on exporting commodities, firm-level investment increases when the domestic currency strengthens. 
Countries on the upper quartile of the ECI indicator only include advanced economies. Thus, the results in column 2 of Table 5 should not be surprising. The estimated real effective exchange rate growth coefficients are negative for these countries, indicating that a decrease in the REER is associated with higher corporate investment, in line with the results in Table 3 above. For economies in the lower quartile of the ECI measure (column 1 of Table 5), the estimated coefficient is positive, suggesting that real exchange rate overvaluation is positively associated with investment at the firm level. This group consists mainly of emerging and developing economies.

Table 5: Economic complexity. The dependent variable is the investment-capital ratio (ICR)

\begin{tabular}{|c|c|c|c|c|}
\hline VARIABLES & $\begin{array}{l}\text { (1) } \\
\text { Sample with ECI } \\
\text { lower than } \\
\text { percentile 25th }\end{array}$ & $\begin{array}{l}\text { (2) } \\
\text { Sample with ECI } \\
\text { higher than } \\
\text { percentile } 75 \text { th }\end{array}$ & $\begin{array}{c}\text { (3) } \\
\text { Sample with ECl } \\
\text { lower than } \\
\text { percentile 25th } \\
\text { and Advanced }\end{array}$ & $\begin{array}{c}\text { (4) } \\
\text { All } \\
\text { Countries }\end{array}$ \\
\hline ICR (t-1) & $\begin{array}{c}0.0603 * * * \\
(0.0101)\end{array}$ & $\begin{array}{c}0.0097 \\
(0.0211)\end{array}$ & $\begin{array}{c}0.0668 * * * \\
(0.0110)\end{array}$ & $\begin{array}{c}0.0701 * * * \\
(0.0085)\end{array}$ \\
\hline Tobin's Q & $\begin{array}{c}0.0385 * * * \\
(0.0052)\end{array}$ & $\begin{array}{c}0.0470 * * * \\
(0.0057)\end{array}$ & $\begin{array}{c}0.0486 * * * \\
(0.0024)\end{array}$ & $\begin{array}{c}0.0427^{* * *} \\
(0.0043)\end{array}$ \\
\hline Cash flow & $\begin{array}{c}0.0040 \\
(0.0083)\end{array}$ & $\begin{array}{c}0.0012 \\
(0.0054)\end{array}$ & $\begin{array}{c}-0.0065 * * * \\
(0.0006)\end{array}$ & $\begin{array}{c}0.0045 \\
(0.0038)\end{array}$ \\
\hline Leverage (t-1) & $\begin{array}{c}-0.0245^{* * *} \\
(0.0036)\end{array}$ & $\begin{array}{c}-0.0164 * * * \\
(0.0020)\end{array}$ & $\begin{array}{c}-0.0271 * * * \\
(0.0071)\end{array}$ & $\begin{array}{c}-0.0203^{* * *} \\
(0.0018)\end{array}$ \\
\hline Change in debt & $\begin{array}{c}0.0652 * * * \\
(0.0086)\end{array}$ & $\begin{array}{c}0.0426 * * * \\
(0.0022)\end{array}$ & $\begin{array}{c}0.0478^{* * *} \\
(0.0046)\end{array}$ & $\begin{array}{c}0.0455^{* * *} \\
(0.0058)\end{array}$ \\
\hline Sales growth (t-1) & $\begin{array}{c}0.0002^{* * *} \\
(0.0001)\end{array}$ & $\begin{array}{c}0.0007^{* * *} \\
(0.0001)\end{array}$ & $\begin{array}{c}0.0001^{* * *} \\
(0.0000)\end{array}$ & $\begin{array}{c}0.0003^{* * *} \\
(0.0001)\end{array}$ \\
\hline REER Growth & $\begin{array}{c}0.0014 * * * \\
(0.0005)\end{array}$ & $\begin{array}{c}-0.0006 * * * \\
(0.0001)\end{array}$ & $\begin{array}{c}-0.0190 * * * \\
(0.0022)\end{array}$ & $\begin{array}{c}0.0071^{* * *} \\
(0.0009)\end{array}$ \\
\hline REER Growth X Economic Complexity Index & & & & $\begin{array}{c}-0.0084^{* * *} \\
(0.0014)\end{array}$ \\
\hline Cboe Volatility Index (VIX) (t-1) & $\begin{array}{l}-0.0058 \\
(0.0057)\end{array}$ & $\begin{array}{l}-0.0003 \\
(0.0029)\end{array}$ & $\begin{array}{c}0.0207^{* * *} \\
(0.0013)\end{array}$ & $\begin{array}{c}-0.0193^{* * *} \\
(0.0040)\end{array}$ \\
\hline Constant & $\begin{array}{c}0.3918^{* * *} \\
(0.1391)\end{array}$ & $\begin{array}{l}0.1391 * * \\
(0.0449)\end{array}$ & $\begin{array}{c}-0.3608 * * * \\
(0.0578)\end{array}$ & $\begin{array}{c}0.6345^{* * *} \\
(0.0857)\end{array}$ \\
\hline Observations & 81,298 & 103,610 & 21,047 & 328,168 \\
\hline R-squared & 0.1023 & 0.0904 & 0.0775 & 0.0869 \\
\hline Number of firms & 12,648 & 15,971 & 3,762 & 39,551 \\
\hline Number of countries & 42 & 10 & 7 & 67 \\
\hline
\end{tabular}

As above, we repeat this specification replacing the real exchange rate growth with the measure of real exchange rate misalignment (Table 6). All the above results hold, except that when using real exchange rate misalignment, less complex advanced economies behave as emerging market and developing economies. In this case, corporate investment needs an overvalued currency to increase (column 3). Thus, this suggests that rather than income, it is the production 
structure what matters the most to understand the effect of real exchange rate misalignment on firm-level investment. ${ }^{17}$ We also find that higher economic complexity is associated with higher firm-level investment (column 4 of Table 6), as one would have expected. Moreover, economic complexity seems to be related to the competitiveness channel, as shown by the negative and statistically significant coefficient of the interaction of the real exchange rate growth and the economic complexity index.

Table 6: Economic complexity. The dependent variable is the investment-capital ratio (ICR)

\begin{tabular}{|c|c|c|c|c|}
\hline VARIABLES & $\begin{array}{l}\text { (1) } \\
\text { Sample with ECl } \\
\text { lower than } \\
\text { percentile 25th }\end{array}$ & $\begin{array}{l}\text { (2) } \\
\text { Sample with } \mathrm{ECl} \\
\text { higher than } \\
\text { percentile } 75 \text { th }\end{array}$ & $\begin{array}{c}(3) \\
\text { Sample with ECl } \\
\text { lower than } \\
\text { percentile } 25 \text { th } \\
\text { and Advanced }\end{array}$ & $\begin{array}{c}\text { (4) } \\
\text { All } \\
\text { Countries }\end{array}$ \\
\hline ICR (t-1) & $\begin{array}{c}0.0593 * * * \\
(0.0107)\end{array}$ & $\begin{array}{c}0.0185 \\
(0.0202)\end{array}$ & $\begin{array}{c}0.0546 * * * \\
(0.0140)\end{array}$ & $\begin{array}{c}0.0755^{* * *} \\
(0.0110)\end{array}$ \\
\hline Tobin's Q & $\begin{array}{c}0.0412 * * * \\
(0.0073)\end{array}$ & $\begin{array}{c}0.0498 * * * \\
(0.0062)\end{array}$ & $\begin{array}{c}0.0621^{* * *} \\
(0.0040)\end{array}$ & $\begin{array}{c}0.0438^{* * *} \\
(0.0045)\end{array}$ \\
\hline Cash flow & $\begin{array}{l}0.0000^{*} \\
(0.0000)\end{array}$ & $\begin{array}{c}0.0000 * * \\
(0.0000)\end{array}$ & $\begin{array}{c}0.0000 * * * \\
(0.0000)\end{array}$ & $\begin{array}{c}0.0000 \\
(0.0000)\end{array}$ \\
\hline Leverage $(\mathrm{t}-1)$ & $\begin{array}{c}-0.0229 * * * \\
(0.0039)\end{array}$ & $\begin{array}{c}-0.0142^{* * *} \\
(0.0008)\end{array}$ & $\begin{array}{c}-0.0209 * * * \\
(0.0051)\end{array}$ & $\begin{array}{c}-0.0258^{* * *} \\
(0.0027)\end{array}$ \\
\hline Interest expense ratio (t-1) & $\begin{array}{l}-0.0003 \\
(0.0126)\end{array}$ & $\begin{array}{c}0.0380^{* * *} \\
(0.0094)\end{array}$ & $\begin{array}{c}0.0278^{* * *} \\
(0.0039)\end{array}$ & $\begin{array}{l}-0.0072 \\
(0.0068)\end{array}$ \\
\hline Change in debt & $\begin{array}{c}0.0683^{* * *} \\
(0.0107)\end{array}$ & $\begin{array}{c}0.0424 * * * \\
(0.0015)\end{array}$ & $\begin{array}{c}0.0468 * * * \\
(0.0056)\end{array}$ & $\begin{array}{c}0.0001 \\
(0.0003)\end{array}$ \\
\hline Sales growth (t-1) & $\begin{array}{c}0.0220^{* *} \\
(0.0101)\end{array}$ & $\begin{array}{c}0.0538^{* * *} \\
(0.0109)\end{array}$ & $\begin{array}{c}0.0085^{* * *} \\
(0.0021)\end{array}$ & $\begin{array}{c}0.0364 * * * \\
(0.0064)\end{array}$ \\
\hline REER Misalignment & $\begin{array}{c}0.0029 * * * \\
(0.0002)\end{array}$ & $\begin{array}{c}-0.0009 * * * \\
(0.0001)\end{array}$ & $\begin{array}{c}0.0034 * * * \\
(0.0003)\end{array}$ & $\begin{array}{c}0.0299 * * * \\
(0.0009)\end{array}$ \\
\hline REER Misalignment X Economic Complexity Index & & & & $\begin{array}{c}-0.0702 * * * \\
(0.0021)\end{array}$ \\
\hline Economic Complexity Index & & & & $\begin{array}{c}1.6894 * * * \\
(0.0322)\end{array}$ \\
\hline Cboe Volatility Index (VIX) (t-1) & $\begin{array}{l}-0.0126 \\
(6.3983)\end{array}$ & $\begin{array}{c}-0.0063^{* *} \\
(0.0024)\end{array}$ & $\begin{array}{l}-0.0066 \\
(0.0119)\end{array}$ & $\begin{array}{c}0.0133^{* * *} \\
(0.0033)\end{array}$ \\
\hline Constant & $\begin{array}{c}0.3631 \\
(60.3613)\end{array}$ & $\begin{array}{l}0.2951^{* *} \\
(0.1112)\end{array}$ & $\begin{array}{c}0.2012 \\
(0.2156)\end{array}$ & $\begin{array}{c}-1.7298^{* * *} \\
(0.0810)\end{array}$ \\
\hline Observations & 66,162 & 95,792 & 14,505 & 299,586 \\
\hline R-squared & 0.1247 & 0.0908 & 0.0938 & 0.0590 \\
\hline Number of firms & 11,520 & 15,337 & 3,007 & 38,790 \\
\hline Number of countries & 42 & 10 & 7 & 67 \\
\hline
\end{tabular}

Notes: All specifications include firm, year, industry-year, and country-year fixed effects. Robust standard errors (clustered by country) are in parentheses. ${ }^{* * *} \mathrm{p}<0.01,{ }^{* *} \mathrm{p}<0.05,{ }^{*} \mathrm{p}<0.1$.

${ }^{17}$ Seven advanced economies are included in this group. The countries and years in this sub-sample are: Australia 1997-2016; Canada 2013-2016; Greece 1997-2016; Hong Kong 1998-2000; New Zealand 1997-2016; Portugal 1997-1999, 2013, 2016; Spain 2016. To check the robustness of this result, we repeated the exercise excluding Portugal and Spain to avoid firms from countries with non-continuous years in the sub-sample. The main results hold. 


\section{Robustness CHECKS}

We performed a battery of robustness checks. Among them, we split the sample between manufacturing and non-manufacturing firms and separately for tradable and non-tradable sectors. The results were mostly aligned with those presented above. We also run the above regressions excluding the countries with the largest number of firms in emerging Asia (China and India, accounting for roughly 65 percent of firms in this group of countries) to test whether the differentiated results were driven by firms in these two countries. But they were not as the results were broadly the same when excluding firms from these two countries. We also removed a few countries with a very limited number of firms-and thus observations. Results held.

\section{CONCLUding ReMARKS}

We use firm-level data to document the impact of real exchange rate movements in corporate investment. The Mundell-Fleming model, a key backbone of open economy macroeconomics, suggests that investment (mainly in the tradable sector) and thus growth, should increase when the currency weakens. When we test for this empirically, we find that for most of the advanced economies, investment in fact increases when the real exchange rate depreciates, in line with this model. For these countries, competitiveness appears to be the channel driving investment. Emerging Asia behaves similarly to advanced economies. However, for all other regions of emerging market and developing economies, as well as for some advanced economies, all being less complex economies, investment increases when the domestic currency appreciates. This evidence lends support to Diaz Alejandro (1963), suggesting that these countries take advantage of the temporary cheaper imported capital goods associated with the stronger real exchange rate and increase investment. Finally, we find that it is precisely economic complexity what determines the relationship between real exchange rates and corporate investment. 


\section{REFERENCES}

Alfaro, L., A.Cuñat, H. Fadinger, and Y. Liu (2017), “The Real Exchange Rate, Innovation, and Productivity,” Harvard Business School Working Paper 18-044 (Massachusetts: Harvard Business School).

Avdjiev, S., V. Bruno, C. Koch, and H.S. Shin (2017), “The Dollar Exchange Rate as a Global Factor: Evidence from Investment,” forthcoming, IMF Economic Review.

Avellan, L. and E. Ferro (2018), Productividad en la Agricultura y Manufactura del Ecuador,” IDB Working Paper, forthcoming (Washington: Inter-American Development Bank).

Caballero. J. (2018), “Corporate Dollar Debt and Depreciations: All's Well that Ends Well?,” IDB Working paper, forthcoming (Washington: Inter-American Development Bank).

Carriere-Swallow, Y., B. Gruss, N. Magud, and F. Valencia (2016), "Monetary Policy Credibility and Exchange Rate Pass-Through,” IMF Working Paper 16/240 (Washington: International Monetary Fund).

Céspedes, L.F., R. Chang, and A. Velasco (2004), "Balance Sheet and Exchange Rate Policy," American Economic Review, vol. 94, No. 4, September, pp. 1183-1193.

Druck, P., N. Magud, and R. Mariscal (2018), “Collateral Damage: Dollar Strength and Emerging Markets’ Growth,” North American Journal of Economics and Finance, Vol. 43, pp. 97-117.

Dao, M., C. Minoui, and J. Ostry (2017), “Corporate Investment and the Real Exchange Rate,” IMF Working Paper 17/183 (Washington: International Monetary Fund).

Diaz Alejandro, C.F. (1963), “A Note on the Impact of Devaluation and the Redistributive Effect,” The Journal of Political Economy, Vol. 71, No. 6 (December), pp. 577-580.

Fleming, J. M. (1962), “Domestic Financial Policies under Fixed and Floating Exchange Rates,” IMF Staff Papers, 9, pp. 369-379.

Hausmann, R. and C.A. Hidalgo (2011), "The Network Structure of Economic Output, Journal of Economic Growth, 16 (2011) 309-342.

Hausmann, R., C.A. Hidalgo, S. Bustos, M. Coscia, S. Chung, J. Jimenez, A. Simoes and M.A. Y1ldırım (2011), “The Atlas of Economic Complexity: Mapping Paths to Prosperity,” Cambridge, MA: Center for International Economics at Harvard University and MIT Press.

Hayashi, F. (1982), “Tobin's Marginal Q and Average Q: A Neoclassical Interpretation,” Econometrica: Journal of the Econometric Society, pp. 213-224.

Krugman, P. (1999), "Balance Sheets, the Transfer Problem, and Financial Crises," International Tax and Public Finance, vol. 6 (November), issue 4, pp. 459-472. 
Krugman, P. and L. Taylor (1978), "Contractionary Effects of Devaluation,” Journal of International Economics, vol. 8, issue 3, pp. 445-456.

Lanau, S. (2017), "The Sectoral Effects of Real Depreciations in Latin America," IMF Working Paper 17/249 (Washington: International Monetary Fund).

Li, D., N. Magud, and F. Valencia (2015), "Financial Shocks and Corporate Investment in Emerging Markets,” IMF Working Paper 15/285 (Washington: International Monetary Fund).

Magud, N. (2008), "On Asymmetric Business Cycles and the Effectiveness of CounterCyclical Fiscal Policies,” 2008, Journal of Macroeconomics, 30 (September), 885-905.

Magud, N. and S. Sosa (2017), "Corporate Investment in Emerging Markets: Commodity Prices Matter," Economia: The Journal of the Latin American Economic Association, Fall 2017.

Mundell, R. (1963), "Capital Mobility and Stabilization Policy under Fixed and Flexible Exchange Rates,” Canadian Journal of Economic and Political Science, 29 (4), pp. 475-485.

Phillips, T., L. Catão, L. Ricci, R. Bems, M. Das, J. Di Giovanni, F. Unsa, M. Castillo, J. Lee, J. Rodriguez, and M. Vargas (2013), "The External Balance Assessment (EBA) Methodology,” IMF Working Papers 13/272 (Washington: International Monetary Fund). 
APPENDIX

Table A1: Countries and number of non-financials firms in the sample

\begin{tabular}{|c|c|c|c|c|c|c|c|c|c|}
\hline \multicolumn{5}{|c|}{ Emerging and Developing Economies } & \multicolumn{5}{|c|}{ Advanced Economies } \\
\hline Country & $\begin{array}{c}\text { No. of } \\
\text { firms }\end{array}$ & $\begin{array}{c}\text { Tradable } \\
(\%) \\
\end{array}$ & $\begin{array}{c}\text { Manufacturing } \\
(\%)\end{array}$ & $\begin{array}{l}\% \text { of total } \\
\text { the sample } \\
\end{array}$ & Country & $\begin{array}{c}\text { No. of } \\
\text { firms }\end{array}$ & $\begin{array}{c}\text { Tradable } \\
(\%) \\
\end{array}$ & $\begin{array}{c}\text { Manufacturing } \\
(\%)\end{array}$ & $\begin{array}{r}\% \text { of total } \\
\text { the sample }\end{array}$ \\
\hline Argentina & 88 & 61.4 & 44.3 & 0.2 & Australia & 1,506 & 62.3 & 18.7 & 3.7 \\
\hline Bahrain & 8 & 37.5 & 25.0 & 0.0 & Austria & 109 & 66.1 & 60.6 & 0.3 \\
\hline Brazil & 345 & 55.9 & 48.1 & 0.9 & Belgium & 147 & 59.2 & 45.6 & 0.4 \\
\hline Bulgaria & 156 & 76.3 & 68.6 & 0.4 & Canada & 1,557 & 69.2 & 25.9 & 3.9 \\
\hline Chile & 187 & 50.8 & 39.0 & 0.5 & Czech Republic & 55 & 47.3 & 40.0 & 0.1 \\
\hline China & 2,845 & 71.0 & 62.5 & 7.0 & Denmark & 195 & 59.0 & 48.2 & 0.5 \\
\hline Colombia & 59 & 57.6 & 44.1 & 0.1 & Estonia & 14 & 35.7 & 35.7 & 0.0 \\
\hline Croatia & 90 & 46.7 & 40.0 & 0.2 & Finland & 175 & 62.9 & 52.6 & 0.4 \\
\hline Egypt & 129 & 66.7 & 56.6 & 0.3 & France & 1,036 & 53.6 & 44.8 & 2.6 \\
\hline Hungary & 47 & 55.3 & 48.9 & 0.1 & Germany & 945 & 57.7 & 51.4 & 2.3 \\
\hline India & 2,284 & 74.0 & 69.2 & 5.7 & Greece & 287 & 53.0 & 39.0 & 0.7 \\
\hline Indonesia & 427 & 63.2 & 39.1 & 1.1 & Hong Kong SAR & 822 & 52.7 & 37.2 & 2.0 \\
\hline Jordan & 107 & 65.4 & 59.8 & 0.3 & Iceland & 20 & 50.0 & 35.0 & 0.0 \\
\hline Kazakhstan & 26 & 53.8 & 34.6 & 0.1 & Ireland & 78 & 59.0 & 37.2 & 0.2 \\
\hline Kenya & 32 & 65.6 & 46.9 & 0.1 & Israel & 381 & 59.1 & 45.7 & 0.9 \\
\hline Kuwait & 93 & 46.2 & 29.0 & 0.2 & Italy & 335 & 57.3 & 51.9 & 0.8 \\
\hline Lebanon & 2 & 50.0 & 50.0 & 0.0 & Japan & 4,404 & 49.0 & 41.2 & 10.9 \\
\hline Lithuania & 36 & 55.6 & 47.2 & 0.1 & Korea & 1,989 & 78.2 & 73.1 & 4.9 \\
\hline Malaysia & 1,073 & 59.7 & 46.5 & 2.7 & Luxembourg & 31 & 74.2 & 45.2 & 0.1 \\
\hline Mauritius & 29 & 48.3 & 27.6 & 0.1 & Netherlands & 249 & 54.2 & 41.0 & 0.6 \\
\hline Mexico & 148 & 52.0 & 47.3 & 0.4 & New Zealand & 149 & 45.6 & 29.5 & 0.4 \\
\hline Morocco & 52 & 63.5 & 46.2 & 0.1 & Norway & 279 & 57.0 & 36.2 & 0.7 \\
\hline Nigeria & 69 & 75.4 & 62.3 & 0.2 & Portugal & 91 & 47.3 & 40.7 & 0.2 \\
\hline Oman & 85 & 62.4 & 50.6 & 0.2 & Singapore & 709 & 59.2 & 44.6 & 1.8 \\
\hline Pakistan & 125 & 86.4 & 80.8 & 0.3 & Slovak Republic & 16 & 68.8 & 68.8 & 0.0 \\
\hline Poland & 452 & 49.8 & 40.5 & 1.1 & Slovenia & 41 & 46.3 & 41.5 & 0.1 \\
\hline Qatar & 25 & 48.0 & 32.0 & 0.1 & Spain & 205 & 47.3 & 39.0 & 0.5 \\
\hline Romania & 111 & 77.5 & 67.6 & 0.3 & Sweden & 527 & 55.4 & 47.2 & 1.3 \\
\hline Russia & 637 & 49.9 & 39.1 & 1.6 & Switzerland & 249 & 64.7 & 59.4 & 0.6 \\
\hline Saudi Arabia & 102 & 65.7 & 56.9 & 0.3 & Taiwan Province of China & 1,887 & 83.6 & 78.0 & 4.7 \\
\hline Serbia & 59 & 72.9 & 64.4 & 0.1 & United Kingdom & 2,007 & 45.6 & 34.4 & 5.0 \\
\hline South Africa & 447 & 55.0 & 32.2 & 1.1 & United States & 7,704 & 53.4 & 43.0 & 19.1 \\
\hline Sri Lanka & 172 & 64.0 & 45.9 & 0.4 & & & & & \\
\hline Thailand & 604 & 61.4 & 51.0 & 1.5 & & & & & \\
\hline Turkey & 291 & 74.9 & 68.7 & 0.7 & & & & & \\
\hline Ukraine & 74 & 82.4 & 66.2 & 0.2 & & & & & \\
\hline United Arab Emirates & 47 & 53.2 & 36.2 & 0.1 & & & & & \\
\hline Venezuela & 20 & 75.0 & 70.0 & 0.0 & & & & & \\
\hline Vietnam & 630 & 59.5 & 45.4 & 1.6 & & & & & \\
\hline Total & 12,213 & 66.5 & 56.5 & 30.2 & Total & 28,199 & 61.2 & 50.2 & 69.8 \\
\hline
\end{tabular}

